\title{
Fireproof Phosphorylated Kraft Lignin/Polyester Based Composites: Green Material for Rocket Propellant Thermal Protection Systems
}

\author{
Jelena Rusmirović ${ }^{1)}$ \\ Vesna Lukić ${ }^{1)}$ \\ Tihomir Kovačevic ${ }^{1)}$ \\ Marica Bogosavljević ${ }^{1)}$ \\ Saša Brzić ${ }^{1)}$ \\ Aleksandar Marinković ${ }^{2)}$ \\ Tatjana Stevanović ${ }^{3)}$
}

\begin{abstract}
Presented study was aimed to investigate the influence of surface functionalization of the industrial kraft lignin (KL) on mechanical and thermal properties of high-performance and fireproof composites based on unsaturated polyester (UPe) resin. In order to improve flame retardant properties, surface of the KL was modified by phosphorylation method in two-step process. First, direct grafting of phosphorus chloride on KL phenolic hydroxyl groups was performed and phosphoric acid ester of $K L$ was formed. In the second step, phosphor ester of $K L$ was recovered by precipitation in cooled isopropyl alcohol and the final obtained product, phosphorylated industrial kraft lignin with methyl terminal groups (KLP) was obtained. KLP mass contents in UPe based composites varied from $0.5 \mathrm{wt} . \%$ to $5.0 \mathrm{wt}$.\%. Structural characterization was done via Fourier Transform-Infrared Spectroscopy (FT-IR). The effects of KLP surface functionalization and KLP mass contents on the UPe tensile properties were studied. Tensile strength $(\sigma)$, elongation $(\varepsilon)$ and Young's modulus of elasticity $(E)$ and Shore A (Sh A) hardness of the UPe/KLP composites were analyzed in relation to the structure of KLP modification. Tensile testing results showed an increase in $\sigma$ of $31 \%$ for UPe/KL sample with $1.0 \mathrm{wt}$ \% KL particles compared to the bare UPe matrix. The origin and cause of fracture that occurred during uniaxial tensile testing were analyzed using stereo microscopy. The obtained composites were tested on fire retardant properties in accordance with the standard test method UL-94V, and composites with 5.0 wt.\% loaded KLP achieved V-1 category
\end{abstract}

Key words: lignin modification, fireproof lignin composites, tensile testing, flame retardancy.

\section{Nomenclature}

UPe - unsaturated polyester

$K L \quad$ - industrial kraft lignin

$K L P \quad$ - phosphorylated industrial kraft lignin

TPS - thermal protection systems

$R P \quad$ - rocket propellants

$P A \quad$ - polymer ablatives

$P P \quad$ - polypropylene

$P E T \quad$ - poly(ethylene terephthalate)

$P U \quad$ - polyurethane

$P G \quad$ - propylene glycol

$L L \quad$ - lignosulphonate lignin

Co-oct - cobalt octoate

$M K P \quad$ - methyl ethyl ketone peroxide

TBT - tetrabutyl titanate catalyst

$\sigma \quad$ - tensile strength

$\varepsilon \quad$ - elongation at break

$E \quad$ - Young's modulus of elasticity

$\operatorname{Sh} A$
$U L-94 \mathrm{~V}$ - test of flammability of plastic materials for parts in devices and appliances

\section{Introduction}

$\mathrm{M}$ ATERIALS for thermal protection systems (TPS) of rocket propellants (RP) play fundamental role for aerospace and military industries [1,2]. Generally, TPS materials are classified in two classes, non-ablative and ablative TPS, according to the mechanism of dissipation of kinetic energy [1]. Polymer ablatives (PA) represent high performance materials used in ablative TPS which have high heat shock resistance, low density, good mechanical strength and thermal insulation capabilities [1]. Thermoset, thermoplastics, elastomers, and thermoplastic elastomers can be used as polymer matrices in ablative TPS [2,3]. Among them, unsaturated polyesters (UPe) have become a valuable and integral part of many industries including aerospace and military industries due to their advanced properties and widespread application [4]. As ablative polymer matrix of TPS material, UPe has to satisfy the prescribed physical,

1) Military Technical Institute (VTI), Ratka Resanovića 1, 11132 Belgrade, SERBIA

2) University of Belgrade, Faculty of Technology and Metallurgy, Karnegijeva 4, 11120 Belgrade, SERBIA

3) Département des sciences du bois et de la forêt, Université Laval, Québec, CANADA

Correspondence to: Jelena Rusmirović; e-mail: jrusmirovic@tmf.bg.ac.rs 
mechanical, thermal and charring properties. In order to increase flame retardancy, char yield and post fire properties (mechanical strength after burning), different micro and nanoparticles and fibrous fillers can be added in UPe matrix [1,2].

In the past decade, the growing interest in development of UPe with improved flame retardancy and charring properties has expressed itself in the emergence of new high performance additives with enhanced flame retardancy [5-7]. Halogenated organic molecules (brominated polystyrene), applied as such or combined with a synergist, typically sodium antimonite, represent effective flame retardancy additives that are commonly used in polyesters [8]. If this system is used in polyesters it can induce degradation/depolymerization caused by acid-catalyzed hydrolysis [8]. Also, halogenated organic molecules do not improve char yield after burning. Moreover, they exhibit significant negative environmental and health effects [7,9]. As brominated flame retardants have been repealed, there is a growing interest in using non-toxic and environmentally friendly alternatives $[7,10]$. The environmental protection has become the aspect of primary importance that has been addressed through emphasized attention on the need for new environmentally friendly flame retardant additives with high yield of produced char [7].

In that manner, using sustainable and bio-renewable resources that produce char after burning get an increasing interest [7]. The huge research efforts have been invested in using lignocellulosic derived polymers, lignin, cellulose and hemicelluloses [11]. At high temperatures, lignin produces naturally remarkable char residue, the formation of which one is of the solutions for improving flame retardancy of polymers $[11,12]$. Produced char residue, actually represents aromatic structure accrues due to rearrangement of lignin backbone [11]. Several studies of lignin flame retardancy in polymer matrices and composites such as polypropylene (PP), polylactide, acrylonitrile-butadiene-styrene, silicone, etc. show that lignin is a promising flame retardant that reduces heat release rate peak for polymer combustion $[13,14]$. The main disadvantage of using lignin in polymer matrices, especially in UPe, is incompatibility with UPe which is caused by structural differences of polyolefin and lignin [15] which can deteriorate the mechanical properties of composite material. It is reported in literature [16] that the blending of PP with bare lignin resulted in materials with almost all of the mechanical properties reduced.

Considering lignin chemical structure, which is generated by coupling of radicals from three main polyphenols/monolignols ( $p$-coumaryl, coniferyl and sinapyl alcohols), it represents a suitable substrate for chemical modification in order to tune polymer thermal properties [12, 17]. The phosphorylation of lignin is proved to be effective in improving its flame retardant performance [7, 11, 12, 17]. Phosphorous-containing lignin based flame retardants act as char promoters [11]. Xing et al. [18] demonstrate that the addition of $30 \mathrm{wt} \%$ of phosphorylated lignin in polyuretane (PU)/polyphenol based foam significantly increases mass residue at $700^{\circ} \mathrm{C}(42.7 \%)$, compared to the pure $\mathrm{PU}(0.2 \%)$. The increased residue can be attributed to the formation of more thermally stable carbonaceous char of phosphorylated lignin [18]. Accumulated char forms protective layer on the surface reducing the heat transfer [10, 19]. Moreover, phosphoric acid, released during thermal decomposition of phosphorous compounds, condenses to polyphosphates and also promotes charring [10].

The main objectives of this work are to gain a better understanding of the underlying principles and mechanisms governing flammability, flame retardancy and char producing and to develop new mechanistic approaches for the emerging new materials for TPS. In this work, the flame retardant behavior of UPe resin containing pristine and phosphorylated industrial kraft lignin (KL and KLP, respectively) is compared. KL and KLP mass contents in UPe based composites is varied from $0.5 \mathrm{wt} \%$ to $5.0 \mathrm{wt} . \%$. The mechanical and thermal properties of composites containing KL and KLP incorporated in UPe matrix were investigated by tensile strength testing, Shore hardness and standard flammability test method, vertical UL-94. This research allowed for understanding the polymer burning process concerning the relation between the additive structural and the flame retardant properties and the effects it induces in UPe matrix. The produced UPe/KLP composites are anticipated for designing the composite thermal insulation for rocket propellant chamber.

\section{Experimental part}

\section{Materials}

Waste poly(ethylene terephthalate) (PET) (supplier RKS Kompoziti Ltd, Čelarevo, Serbia), was collected from soft drink bottles, and used for UPe resin synthesis. Soft drink bottles were crushed into small pieces $(\approx 0.5-0.5 \mathrm{~cm})$ and washed with solvents (ethanol and dichloromethane) in order to remove impurities. Kraft lignin with a low sulfonate content, phosphorus oxychloride $\left(\mathrm{POCl}_{3}\right.$, purity $\left.99 \%\right)$, chloroform $\left(\mathrm{CHCl}_{3}\right)$, maleic anhydride (MA), tetrabutyl titanate (TBT), hydroquinone (HQ), $N$-methyl-2-pyrrolidone, isopropyl alcohol, propylene glycol (PG), diethyl ether, methyl ethyl ketone peroxide (MKP), cobalt octoate (Co-oct) were purchased from Sigma Aldrich and used as received.

\section{Synthesis of unsaturated polyester resin}

UPe resin was synthesized from MA and products obtained by PET depolymerization with PG in the presence of TBT catalyst. Following the glycolysis procedure described earlier in the literature [20], molar ratio of PET and PG used for glycolysis was $1: 2.2$ and reaction was maintained at $210^{\circ} \mathrm{C}$ for 5 hours. After completion of the glycolysis reaction, mixture was cooled down to $90^{\circ} \mathrm{C}$ and nitrogen was introduced in reactor in order to provide inert atmosphere. $123 \mathrm{~g}$ of MA $(1.25 \mathrm{~mol})$ was added and temperature was raised to $115^{\circ} \mathrm{C}$ and maintained to the tuned temperature for $1 \mathrm{~h}$. Afterwards, continuous temperature increase was achieved at a heating rate of $15^{\circ} \mathrm{C} / \mathrm{h}$ until $150^{\circ} \mathrm{C}$, when the toluene $(6 \mathrm{wt} \%)$ was added as the agent for azeotropic removal of water. The temperature increase was continued until $210^{\circ} \mathrm{C}$. The reaction was carried out until the acid number value decreased below $30 \mathrm{mg} \mathrm{KOH} / \mathrm{g}$, after which the resin obtained was cooled down to $120^{\circ} \mathrm{C}$ and a solution of the $0.03 \mathrm{~g} \mathrm{HQ}$ in $2 \mathrm{~mL}$ of methanol was added. After the completion of the reaction, the low boiling compounds and reactant residues were removed from the product by vacuum distillation, after what the obtained UPe resin was cooled down to $100^{\circ} \mathrm{C}$ and dissolved in styrene $(40 \mathrm{wt} \%)$ containing equivalent amount of inhibitor. Viscosity of UPe was $2880 \mathrm{mPa} \cdot \mathrm{s}$.

\section{Phosphorylation of industrial kraft lignin}

The chemical modification of lignin (Scheme 1) was performed according to the literature procedure [7, 19] as follows: $10 \mathrm{~g}$ of $\mathrm{KL}$ was dissolved in $100 \mathrm{~mL}$ mixture of $\mathrm{CHCl}_{3} / N$-methyl-2-pyrrolidone $(50 \mathrm{v}: 50 \mathrm{v})$ and heated to $100^{\circ} \mathrm{C}$. After dissolving of lignin, temperature was reduced 
down to $50^{\circ} \mathrm{C}$ and $6.5 \mathrm{~g}$ of $\mathrm{POCl}_{3}$ was added dropwise to the lignin solution. The reaction mixture was heated to $60^{\circ} \mathrm{C}$ and reaction was carried out for $17 \mathrm{~h}$ at maintained temperature. The obtained product, phosphorylated lignin was recovered by precipitation in cooled isopropyl alcohol and washed by repeating of centrifugation/sonication process three times with isopropyl alcohol and diethyl ether. KLP was dried at $60^{\circ} \mathrm{C}$ in vacuum oven.

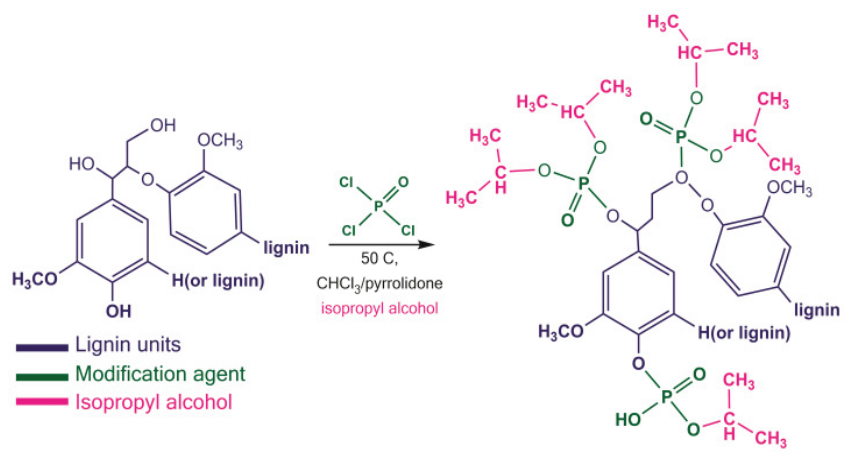

Scheme 1. Chemical modification of kraft lignin

\section{UPe/KLP composites preparation (emulsion blending method)}

Composites based on UPe and pristine or phosphorylated KL were prepared using emulsion blending method by dispersing of $0.5,1.0$ and 5 wt.\% of KL or KLP in UPe matrix. The homogenization of KLP with UPe was achieved by using a modified laboratory homogenizer. The pure UPe and composites were cured using MKP (1.5 wt.\%) as the initiator and Co-oct $(0.5 \mathrm{wt} . \%)$ as the accelerator in standard polytetrafluoroethylene molds for uniaxial tensile tests (ASTM D882 test standard dimension $60 \times 10 \times 4 \mathrm{~mm}$ with narrowed neck area $-15 \times 4 \times 4 \mathrm{~mm}$ ) and flammability measurements. The uniaxial tensile test of cured UPe/KLP standard sample is presented in Fig.1.

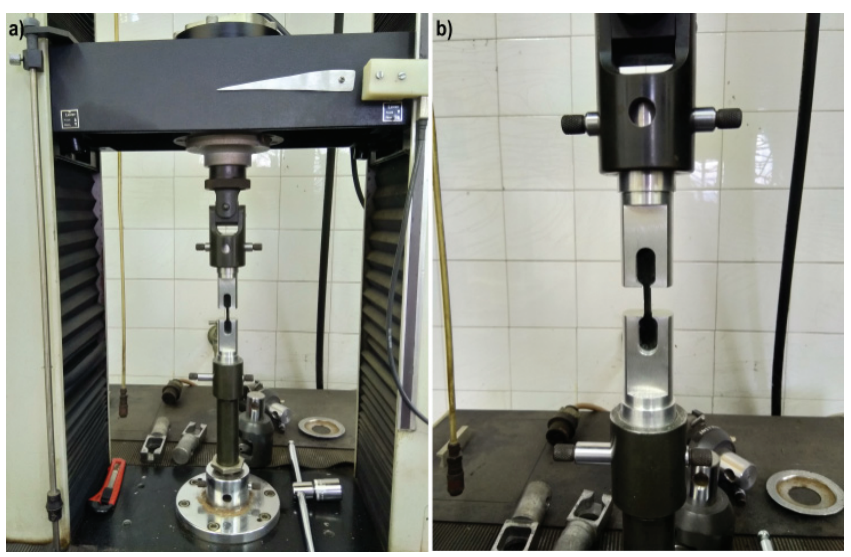

Figure 1. Uniaxial tensile test of cured ASTM D882 standard test molds using an Instron tester 1122

Table 1. Compositions for preparation of neat UPe, UPe/KL and UPe/KLP composites

\begin{tabular}{||c|c|c|c|c|c||}
\hline Sample & $\begin{array}{c}U P e \\
{[\mathrm{~g}]}\end{array}$ & $\begin{array}{c}\text { STR } \\
{[\mathrm{g}]}\end{array}$ & $\begin{array}{c}K L / K L P \\
{[\mathrm{~g}]}\end{array}$ & $\begin{array}{c}\text { MKP } \\
{[\mathrm{mL}]}\end{array}$ & $\begin{array}{c}\text { Co-oct } \\
{[\mathrm{mL}]}\end{array}$ \\
\hline \hline $\mathrm{UPe}$ & 3.0 & 0.25 & - & 0.50 & 0.17 \\
\hline $\mathrm{UPe} / \mathrm{KL}_{(\mathrm{a})}$ & 3.0 & 0.25 & 0.015 & 0.50 & 0.17 \\
\hline $\mathrm{UPe} / \mathrm{KL}_{(\mathrm{b})}$ & 3.0 & 0.25 & 0.030 & 0.50 & 0.17 \\
\hline $\mathrm{UPe} / \mathrm{KL}_{(\mathrm{c})}$ & 3.0 & 0.25 & 0.300 & 0.50 & 0.17 \\
\hline $\mathrm{UPe} / \mathrm{KLP}_{(\mathrm{a})}$ & 3.0 & 0.25 & 0.015 & 0.50 & 0.17 \\
\hline $\mathrm{UPe} / \mathrm{KLP}_{(\mathrm{b})}$ & 3.0 & 0.25 & 0.030 & 0.50 & 0.17 \\
\hline $\mathrm{UPe} / \mathrm{KLP}_{(\mathrm{c})}$ & 3.0 & 0.25 & 0.300 & 0.50 & 0.17 \\
\hline
\end{tabular}

\section{Characterization methods}

Fourier Transform Infrared Spectroscopy (FT-IR) spectra of the cured UPe/KL(a-c) and UPe/KLP(a-c) composites samples were recorded in absorbance mode using a Nicolet ${ }^{\mathrm{TM}}$ iS ${ }^{\mathrm{TM}} 10$ FT-IR Spectrometer (Thermo Fisher SCIENTIFIC) with Smart iTR $^{\mathrm{TM}}$ Attenuated Total Reflectance (ATR) Sampling accessories, within a range of $400-4000 \mathrm{~cm}^{-1}$, at a resolution of 4 $\mathrm{cm}^{-1}$ and in 20 scan modes.

Shore A Hardness (Sh A) of cured composites samples was determined using Zorn Stendal DDR testing device. The three measurements were performed in order to determine mean values of Sh A hardness.

Uniaxial tensile measurements of standard cured samples (ASTM D882) [21] were performed using an Instron tester 1122. All tests were performed at $20^{\circ} \mathrm{C}$ adjusted at crosshead speed of $1 \mathrm{~mm} \mathrm{~min}^{-1}$.

Stereo microscope (Leica M205A) with Leica DFC295 camera was used to study structure of the fracture after uniaxial tensile testing.

KL and KLP particle size was determined using Particle Size Analyzer, Anton Paar 1090 L/D in liquid mode using isopropyl alcohol as solvent. The Kalliope ${ }^{\mathrm{TM}}$ Software was used for operating PSA analyzer. The mean diameter was calculated by volume.

Viscosity of synthesized UPe resin was determined by standard test method ISO 2555 using the Brookfield viscometer [22]. The standard HB4 spindle rotation rate was 5 rpm $\min ^{-1}$.

Flame resistant properties were analyzed by vertical UL-94 flammability test [23]. The classification of materials according to the UL-94 testing results is shown in Table 2, while the schematic illustration is shown in Fig.2.

Table 2. Classification of materials according to the UL-94 testing results

\begin{tabular}{|l|c|c|c||}
\hline \multicolumn{1}{|c|}{ Criteria } & V-0 & V-1 & V-2 \\
\hline \hline $\begin{array}{l}\text { After flame time for each individual flaming } \\
\text { After flame and glow time for each individual } \\
\text { specimen, after second flaming }\end{array}$ & $\leq 10 \mathrm{~s}$ & $\leq 30 \mathrm{~s}$ & $\leq 30 \mathrm{~s}$ \\
\hline Total after flame time for any condition set & $\leq 50 \mathrm{~s}$ & $\leq 250 \mathrm{~s}$ & $\leq 250 \mathrm{~s}$ \\
\hline Cotton indicator ignited by flaming drops & No & No & Yes \\
\hline $\begin{array}{l}\text { After flame and afterglow time of any speci- } \\
\text { men up to the holding clamp }\end{array}$ & No & No & No \\
\hline
\end{tabular}

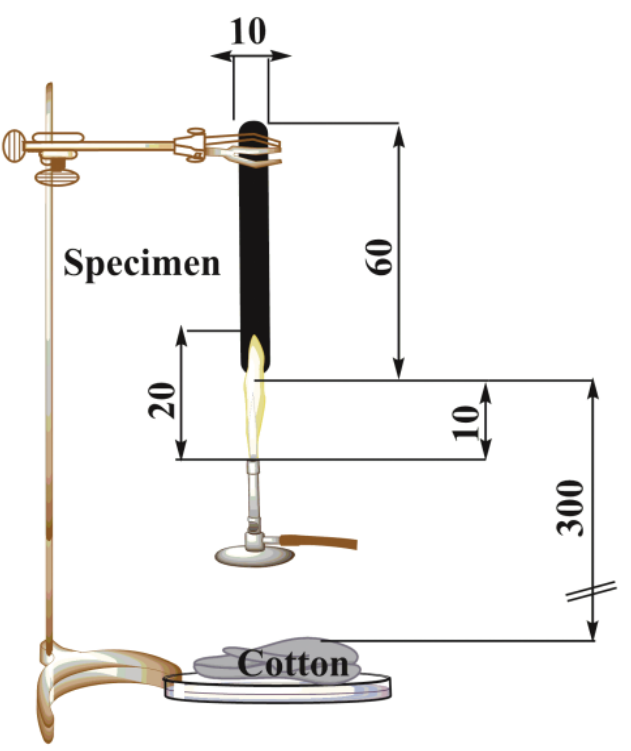

Figure 2. Schematic illustration of UL-94 test 


\section{Results}

\section{Average particle size testing}

The KL particle size depends on its chemical structure and molecular weight, and affects the modification, preparation and the formulation of lignin-based advanced polymers [24]. Fig. 3 reports the KL mean particle diameter obtained from Particle Size Analyzer in liquid mode using isopropyl alcohol as solvent. KL particles have $33.4 \mu \mathrm{m}$ mean diameter and represent suitable substrate for chemical modification and incorporation in polymer matrices. Moreover, compared with lignosulphonate lignin (LL), KL shows lower tendency to form aggregates [24].

After modification, mean diameter of KLP particles as well as uniformity of particle size distribution decreases (Fig.3). Phosphorylated lignin has $11.2 \mu \mathrm{m}$ mean diameter. Lower particles diameter can provide better dispersibility in polymer matrix and improve mechanical properties as well.

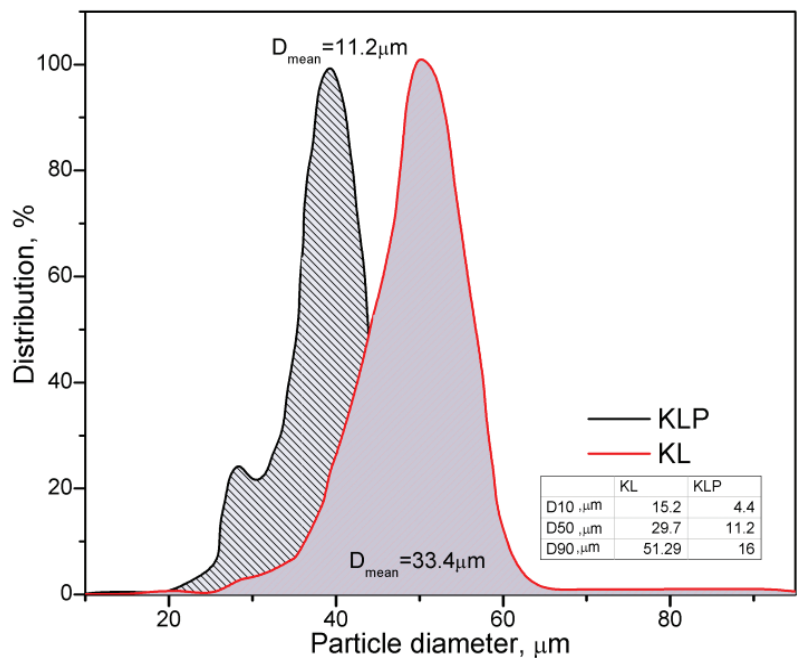

Figure 3. KL and KLP particle diameter distribution

\section{FT-IR analysis results}

Structural characterization of neat and functionalized KL and successfulness of the performed modification method were performed using FT-IR analysis. The peak around 3500 $\mathrm{cm}^{-1}$ in the FT-IR spectra of KL and KLP (Fig.4 and Table 3) originates from both, aliphatic and aromatic $\mathrm{O}-\mathrm{H}$ vibration [13]. Intensity of this band is reduced after phosphorylation [13]. The $\mathrm{C}-\mathrm{H}$ vibrations of methylene $\left(\mathrm{CH}_{2}\right)$ groups are detected at 2920 and $2820 \mathrm{~cm}^{-1}$ [13]. These bands are overlapped with $\mathrm{C}-\mathrm{H}$ stretching vibrations of methyl $\left(\mathrm{CH}_{3}\right)$ group from isopropyl moiety. After modification, the band attributed to stretching vibration of P-O-KL appeared at 1030 $\mathrm{cm}^{-1}$. These changes indicate that phosphorus groups were successfully grafted onto the lignin molecules [13]. The narrow peaks between 2940 and $2850 \mathrm{~cm}^{-1}$, observed for $\mathrm{UPe} / \mathrm{KL}$ and UPe/KLP samples, originate from $\mathrm{C}-\mathrm{H}$ stretching vibrations of $\mathrm{CH}_{2}$ and methyl $\left(\mathrm{CH}_{3}\right)$ groups, respectively, while corresponding bending vibrations appeared at 1452 and $1364 \mathrm{~cm}^{-1}$ in FT-IR spectra of all composites [20]. The intensive peak at $1720 \mathrm{~cm}^{-1}$ appears due to stretching vibration of ester $\mathrm{C}=\mathrm{O}$ groups present in terephthaloyl moiety [20]. Skeletal vibrations of $\mathrm{C}=\mathrm{C}$ double bonds from phenyl core can be observed at $1647-1590 \mathrm{~cm}^{-1}$ [20]. Two narrow adsorption peaks identified at about 728 and $700 \mathrm{~cm}^{-1}$ are assigned to the skeletal $\gamma(\mathrm{CH})$ vibrations of phenyl core [20].
Table 3. FT-IR analysis results

\begin{tabular}{|c|c|c|c|c|c||}
\hline Sample & $\begin{array}{c}v_{\text {as }}\left(\mathrm{CH}_{3}\right) \\
{\left[\mathrm{cm}^{-1}\right]}\end{array}$ & $\begin{array}{c}v_{\text {as }}\left(\mathrm{CH}_{3}\right) \\
{\left[\mathrm{cm}^{-1}\right]}\end{array}$ & $\begin{array}{c}v_{\text {as }}\left(\mathrm{CH}_{2}\right) \\
{\left[\mathrm{cm}^{-1}\right]}\end{array}$ & $\begin{array}{c}v_{\mathrm{s}}\left(\mathrm{CH}_{2}\right) \\
{\left[\mathrm{cm}^{-1}\right]}\end{array}$ & $\begin{array}{c}v(\mathrm{OH}) \\
{\left[\mathrm{cm}^{-1}\right]}\end{array}$ \\
\hline \hline $\mathrm{KL}$ & 2920 & 2820 & 2920 & 2820 & 3500 \\
\hline $\mathrm{KLP}$ & 2920 & 2820 & 2920 & 2820 & 3500 \\
\hline $\mathrm{UPe}$ & 2940 & 2850 & 2940 & 2850 & - \\
\hline $\mathrm{UPe} / \mathrm{KL}_{(\mathrm{a})}$ & 2940 & 2850 & 2940 & 2850 & - \\
\hline $\mathrm{UPe} / \mathrm{KL}_{(\mathrm{b})}$ & 2940 & 2850 & 2940 & 2850 & - \\
\hline $\mathrm{UPe} / \mathrm{KL}_{(\mathrm{c})}$ & 2940 & 2850 & 2940 & 2850 & - \\
\hline $\mathrm{UPe} / \mathrm{KLP}_{(\mathrm{a})}$ & 2940 & 2850 & 2940 & 2850 & - \\
\hline $\mathrm{UPe} / \mathrm{KLP}_{(\mathrm{b})}$ & 2940 & 2850 & 2940 & 2850 & - \\
\hline $\mathrm{UPe} / \mathrm{KLP}_{(\mathrm{c})}$ & 2940 & 2850 & 2940 & 2850 & - \\
\hline
\end{tabular}

Table 3. FT-IR analysis results (continuation)

\begin{tabular}{|c|c|c|c|c|}
\hline Sample & $\begin{array}{c}\gamma(\mathrm{C}=\mathrm{C}) \\
{\left[\mathrm{cm}^{-1}\right]}\end{array}$ & $\begin{array}{c}\gamma(\mathrm{C}-\mathrm{H}) \\
{\left[\mathrm{cm}^{-1}\right]}\end{array}$ & $\begin{array}{c}\mathrm{P}-\mathrm{O}-\mathrm{KL} \\
{\left[\mathrm{cm}^{-1}\right]}\end{array}$ & $\begin{array}{c}v \mathrm{~s}(\mathrm{C}=\mathrm{O}) \\
{\left[\mathrm{cm}^{-1}\right]}\end{array}$ \\
\hline $\mathrm{KL}$ & 1590 & & - & - \\
\hline $\mathrm{KLP}$ & 1590 & & 1130 & - \\
\hline $\mathrm{UPe}$ & 1610 & 700,729 & - & 1720 \\
\hline $\mathrm{UPe} / \mathrm{KL}(\mathrm{a})$ & 1610 & 700,729 & - & 1720 \\
\hline $\mathrm{UPe} / \mathrm{KL}(\mathrm{b})$ & 1610 & 700,729 & - & 1720 \\
\hline $\mathrm{UPe} / \mathrm{KL}(\mathrm{c})$ & 1610 & 700,729 & - & 1720 \\
\hline $\mathrm{UPe} / \mathrm{KLP}(\mathrm{a})$ & 1610 & 700,729 & - & 1720 \\
\hline $\mathrm{UPe} / \mathrm{KLP}(\mathrm{b})$ & 1610 & 700,729 & - & 1720 \\
\hline $\mathrm{UPe} / \mathrm{KLP}(\mathrm{c})$ & 1610 & 700,729 & - & 1720 \\
\hline
\end{tabular}

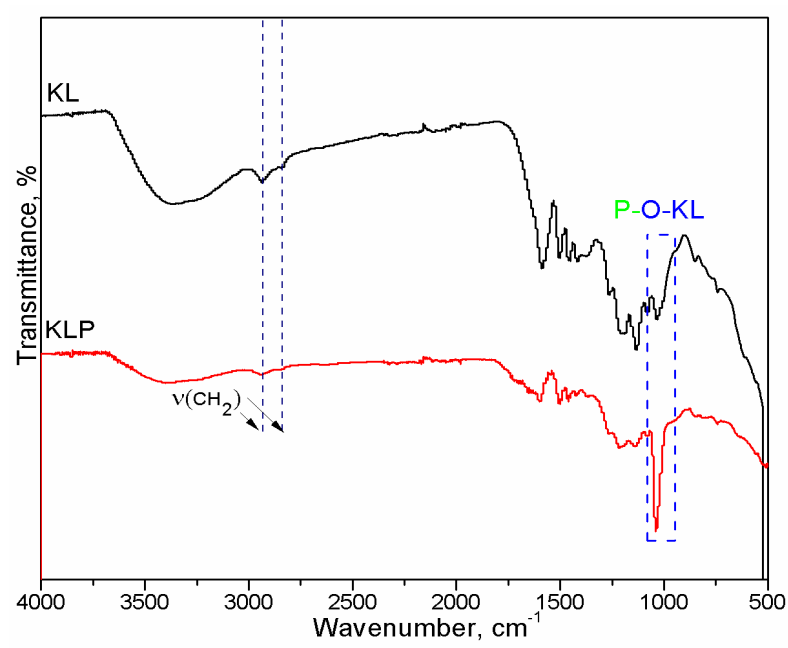

Figure 4. KL and KLP FT-IR spectrum

\section{Mechanical testing results}

When polymer material is exposed to a load, produced deformation can be considered as a sum of ordinary elastic deformation, high elastic deformation and viscous deformation [25]. Fillers addition and good dispersion in polymeric matrix may improve the polymer mechanical properties due to all main loads and restrictive deformation induced by external stress are hindered by the fillers [26]. As shown in Fig. 5 and in Table 4, the tensile strength $(\sigma)$ for the $\mathrm{UPe} / \mathrm{KL}(\mathrm{a}-\mathrm{c})$ composites increases continuously with increasing the KL content up to $1.0 \mathrm{wt} . \%$ (UPe/KL(b)), while further loading of KL decreases $\sigma$. Values of elongation at brake $(\varepsilon)$ for all $\mathrm{UPe} / \mathrm{KL}(\mathrm{a}-\mathrm{c})$ composites are higher than $\varepsilon$ value of cured neat UPe resin. The maximal elongation at break is obtained for UPe/KL(c) composite sample. The improvement in tensile strength of the UPe matrix reinforced with pristine $\mathrm{KL}$ is the consequence of good dispersibility and interfacial adhesion between the pristine filler and polymer matrix. The opposite is found for UPe/KLP composites. 
The tensile strength value increases only in the case of 0.5 wt.\% loading of KLP (UPe/KLP(a)), while further loading of KLP decreases $\sigma$. All UPe/KLP composites show lower values of elongation at break, but higher values of tensile modulus. These results can be attributed to the steric hindrance of the methylene group from the isopropyl alcohol moiety. The values of elongation at break $(\varepsilon)$ and tensile modulus $(E)$ are given in Table 4 .

Energy absorption (EA) of the UPe/KL(a-c) and $\mathrm{UPe} / \mathrm{KLP}(\mathrm{a}-\mathrm{c})$ composites is determined as the area traced out by the stress-strain curves and the $E A$ values are shown in Table 4.

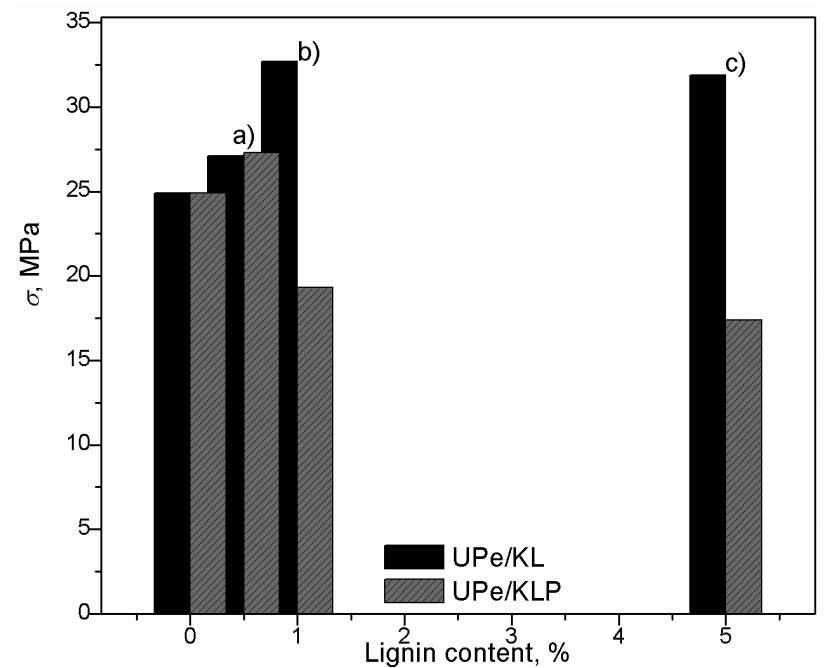

Figure 5. The stress at break of the cured UPe and UPe/KL(a-c) and $\mathrm{UPe} / \mathrm{KLP}(\mathrm{a}-\mathrm{c})$ composites

The results indicate that $E A$ of the UPe/KL based composites increases with KL loading. Values range from a $53.29 \mathrm{~J} \cdot \mathrm{cm}^{-3}$ for neat cured UPe to $109.81 \mathrm{~J} \cdot \mathrm{cm}^{-3}$ for UPe/KL(c) composites. Loading of KL results in increase of specific energy absorption capability of the KL reinforced composites [27]. The opposite is found for $\mathrm{UPe} / \mathrm{KLP}$ based composites. The minimum $E A$ value is observed with loading of $5.0 \mathrm{wt} . \%$ of KLP particles which indicates the highest stiffness of that cured material [27]. The hardness of UPe matrix increases with loading of KLP particles in all tasted mass content. This can be attributed to the lower diameter size for KLP lignin. For KL reinforced composites, the ShA hardness increase only with the highest KL particle loading (5.0 wt.\%), while loading of 0.5 and $1.0 \mathrm{wt} . \% \mathrm{KL}$ particles causes slight decrease of Sh A values.

Table 4. The values of stress at break $(\sigma)$, elongation at break $(\varepsilon)$, tensile modulus $(E)$, energy adsorption $(E A)$ and Shore A (Sh A) hardness

\begin{tabular}{|c|c|c|c|c|c||}
\hline \hline Sample & $\begin{array}{c}\sigma \\
{[\mathrm{MPa}]}\end{array}$ & $\begin{array}{c}E \\
{[\%]}\end{array}$ & $\begin{array}{c}E \\
{[\mathrm{GPa}]}\end{array}$ & $\begin{array}{c}E A \\
{\left[\mathrm{~J} \mathrm{~cm}^{-3}\right]}\end{array}$ & Sh A \\
\hline \hline $\mathrm{UPe}$ & 24.9 & 4.32 & 2.38 & 53.29 & $83.33 \pm 1.15$ \\
\hline $\mathrm{UPe} / \mathrm{KL}(\mathrm{a})$ & 27.1 & 5.81 & 1.54 & 73.37 & $82.67 \pm 4.73$ \\
\hline $\mathrm{UPe} / \mathrm{KL}(\mathrm{b})$ & 32.7 & 6.66 & 2.03 & 107.37 & $81.00 \pm 7.21$ \\
\hline $\mathrm{UPe} / \mathrm{KL}(\mathrm{c})$ & 31.9 & 7.36 & 1.90 & 109.81 & $89.33 \pm 6.11$ \\
\hline $\mathrm{UPe} / \mathrm{KLP}(\mathrm{a})$ & 27.3 & 3.90 & 5.55 & 45.48 & $90.00 \pm 2.02$ \\
\hline $\mathrm{UPe} / \mathrm{KLP}(\mathrm{b})$ & 19.3 & 4.29 & 5.99 & 34.05 & $90.00 \pm 3.00$ \\
\hline $\mathrm{UPe} / \mathrm{KLP}(\mathrm{c})$ & 17.4 & 2.47 & 6.15 & 18.59 & $89.67 \pm 2.30$ \\
\hline
\end{tabular}

Stereomicroscope study of damage mechanisms in UPe/KL and UPe/KLP composites submitted to uniaxial tensile testing

Fractography reveals important clues about the cause of the fracture and therefore plays an important role in determining the cause of the failure [28]. Fractographic analysis involves the examination and interpretation of the surfaces of the fracture [28-30]. As an instrument of choice for the preliminary fracture surface examination, the stereo zoom optical microscope, at moderate magnifications, gives complete information about the origin and cause of the fracture [28].

Irreversible deformation mechanisms in polymers depend on polymer nature (ductile or brittle) and may fall into two basic categories: dilatational, etc. crazes, voids, and micro cracks, or non-dilatational, etc. shear bands, or a mixture of both mechanisms. Brittle polymers, such as thermosetting polymers (polystyrene, UPe, epoxy resin, etc.), are known to fracture at relatively low elongations in tension (2 to 4\%) with crazing and micro cracking as the dominant failure mechanism [28]. Brittle fractures occur on a macroscopic level with little or no gross plastic deformation [28-30]. Stereo microsope images of intersection fractures of cured $\mathrm{UPe}, \mathrm{UPe} / \mathrm{KLP}(\mathrm{a}-\mathrm{c})$ and UPe/KL(a-c) composites submitted to uniaxial tensile testing are presented in Fig.6.
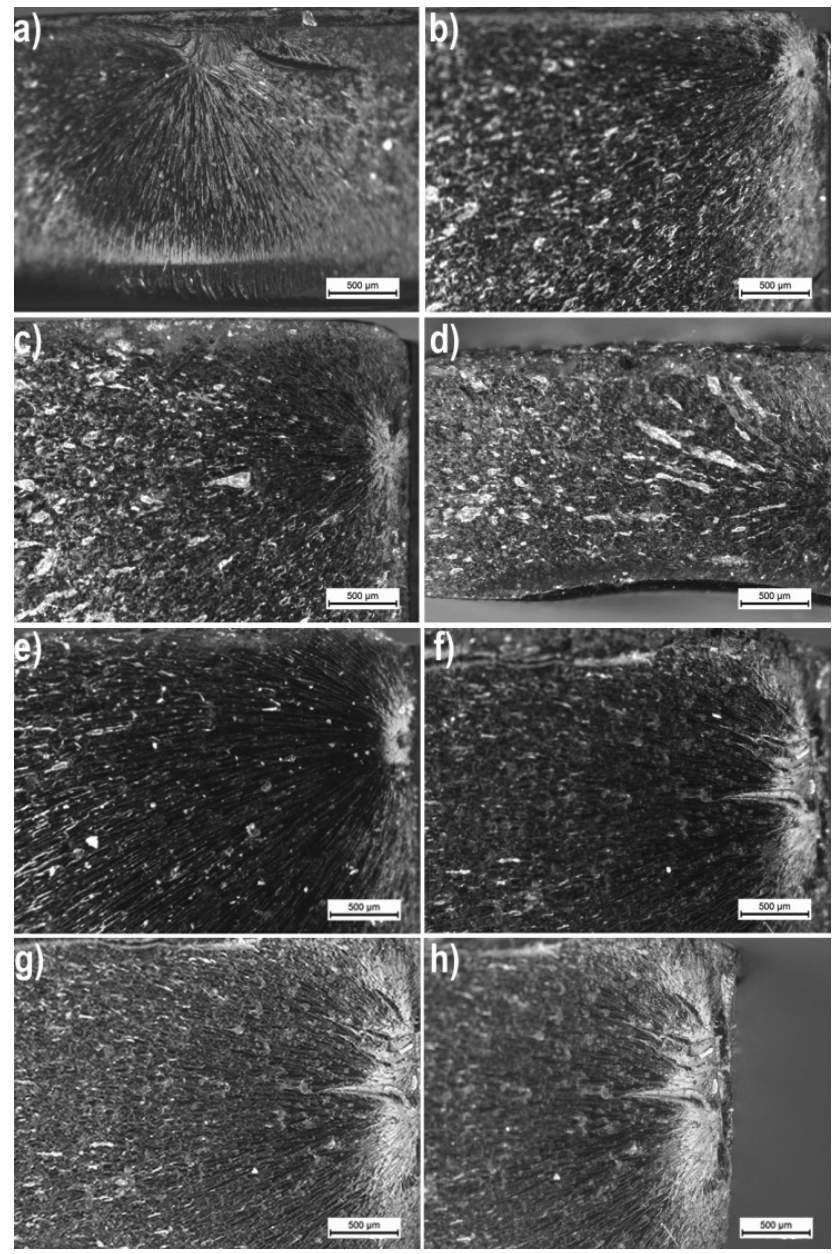

Figure 6. Stereomicrospe images of intersection fractures of cured a) UPe b) $\mathrm{UPe} / \mathrm{KLP}(\mathrm{a}), \mathrm{c}) \mathrm{UPe} / \mathrm{KLP}(\mathrm{b}), \mathrm{d}) \mathrm{UPe} / \mathrm{KLP}(\mathrm{c}), \mathrm{e}) \mathrm{UPe} / \mathrm{KL}(\mathrm{a}), \mathrm{f}) \mathrm{UPe} / \mathrm{KL}(\mathrm{b}), \mathrm{g}$ ) and h) $\mathrm{UPe} / \mathrm{KL}$ (c) composites submitted to uniaxial tensile testing

As it can be seen from Fig.6, crack initiation in all tested cured samples is preceded by craze formation [28], in the most tensile loaded part (neck of the standard sample). Geometrically, observed crazes are planar defects similar to a crack that begin with micro void formation under the action of the hydrostatic tension and have dimensions much larger than thickness [28]. After crazing has been initiated, the voids increase in size and elongate perpendicular the direction of the maximum principal tensile stress [28]. The UPe matrix among the voids also undergoes gradual elongation to form thin fibrils. The deformation of a craze frequently leads to the initiation of a true crack [28]. As the craze faces separate, the craze fibrils increase in length, while their diameters contract 
in the cured UPe/KL (a-c) samples (Fig.6 e-h), while opposite was found in samples with loaded KLP particles. It can be explained by formation of agglomerated KLP particles according to the stearic hindrance of methyl group that cause higher craze fibrils diameter increase. When the longitudinal strain in the fibrils exceeds the maximum extensibility of the molecular network, they rupture and form a crack.

\section{Thermal stability testing results}

Thermal stability of the cured UPe, UPe/KL(c) and $\mathrm{UPe} / \mathrm{KLP}(\mathrm{c})$ composites was determined via set of vertical UL-94V tests (Test of Flammability of Plastic Materials for Parts in Devices and Appliances) [23]. Test describes the material tendency to extinguish or to spread the flame after ignition of the composite. Samples are classified in four categories: NC (not classified), V-2, V-1 and V-0 (Table 2). The experimental set-up for thermal stability vertical tests is shown in Fig.7.

The cured samples with size of $60 \times 10 \times 4 \mathrm{~mm}$ are used for thermal stability tests. A blue flame with a $20 \mathrm{~mm}$ in height is applied for $10 \mathrm{~s}$ to the bottom edge of the vertical specimen, after what the flame is removed and the after flame time required to extinguish the ignited material is recorded. The flame is reapplied for another $10 \mathrm{~s}$ and the time to extinguish is recorded. There is a possibility of specimen dripping during the burning test which can cause inflame a piece of cotton placed below the standard apparatus.

As expected, cured neat UPe specimens exhibit poor fire properties, with instantaneously dripping, whereas the inflamed drops burning the cotton. The cured UPe/KLP(c) composite and neat UPe after UL-94V test are shown in Figure 8. It can be observed that there is no formation of protected carbonized layer (chair) during the burning of neat UPe resin. The UPe/KL(c) composite shows the same response toward flame exposure as neat UPe dripping and ignition a piece of cotton below the sample which burns more than $30 \mathrm{~s}$.

The introduction of $5.0 \mathrm{wt} . \%$ of phosphorylated KL allows an improvement in the fire reaction of UPe composites. The presence of KLP in the UPe matrix allows the promotion of a char on the surface sample, and then a reduction in dripping. Moreover, the UPe/KLP(c) sample is self-extinguished in 25 s. According to the UL-94V test, the UPe/KLP(c) sample can be classified in V-1 category.
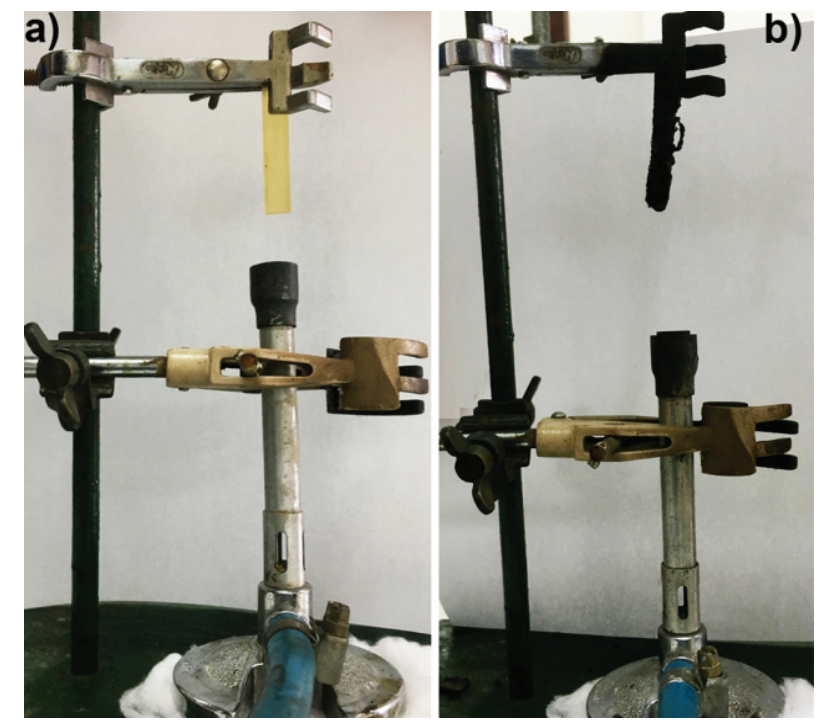

Figure 7. a) Neat UPe resin before UL $94 \mathrm{~V}$ test and b) UPe/KLP(c) composite after UP 94V test

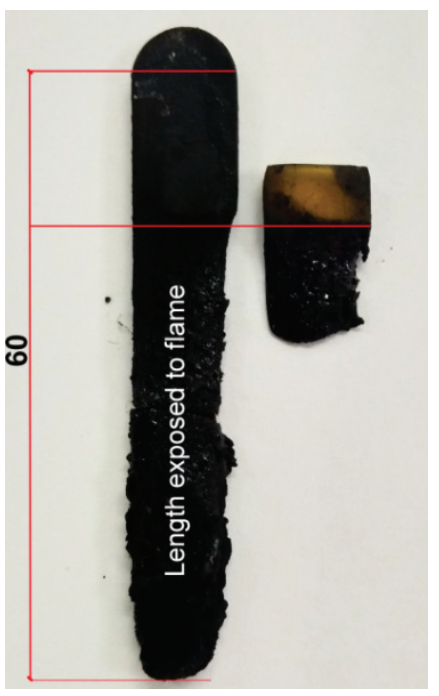

Figure 8. Cured UPe/KLP(c) composite (left) and neat UPe (right) after 94V test

\section{Conclusion}

This study explored the valorization of industrial kraft lignin as flame retardant additive in unsaturated polyester resin based on products of catalytic depolymeriyzation of waste PET. The charring capacity of lignin, the carbon richest biomass constituent, makes it an interesting flame retardant material. In presented work phosphorylated kraft lignin was produced using simple one-step procedure. The successfulness of the performed procedure, direct grafting of phosphorus chloride on kraft lignin surface hydroxyl groups, and formation of phosphoric acid ester were confirmed via Fourier Transform Infrared Spectroscopy. Prepared modified lignin was used as a flame retardant additive in thermosetting matrix consisting of recycled UPe. KLP lignin improves fire resistance properties of the UPe resin and prepared $\mathrm{UPe} / \mathrm{KLP}(\mathrm{c})$ composite achieves $\mathrm{V}-1$ category. The mechanical properties (tensile strength and elongation at break) decrease with KLP loading in UPe matrix, while the values of tensile moduli increase. Unmodified kraft lignin was determined to improve the tensile properties of the cured UPe resin. Stereo microscopy analysis demonstrated that crack initiation under uniaxial tensile loaded was preceded by craze formation in the most tensile loaded part (neck of the standard sample). The obtained results encourage potential application of the prepared material based on recycled UPe and kraft lignin, as a composite thermal insulation for rocket propellant chamber.

\section{References}

[1] NATALI,M., KENNY,J.M., TORRE,L.: Science and Technology of Polymeric Ablative Materials for Thermal Protection Systems and Propulsion Devices, A Review, Progress in material Science, 2016, Vol.84, pp.192-275.

[2] KOO,J.H., NATAli,M., TATE,J., ALlCORN,E.: Polymer Nanocomposites as Ablative Materials: A Comprehensive Review, International Journal of Energetic Materials and Chemical Propulsion, Vol.12, No.2, pp.119-162.

[3] AGRAWAL,J.P., CHOWK,M.P., SATPUTE,R.S.: Study on Mixed Glycols-based Semi-flexible Unsaturated Polyester Resins for Inhibition of Rocket Propellants, The British Polymer Journal, 1982, Vol.14, pp. $29-34$.

[4] RADUlOVIĆ,J., JOVANOVIĆ,S., DŽELEBDŽIĆ,N.: Injection Moulded Polycarbonate Covers of Rocket Launcher Tubes, Scientific Technical Review, 2013, Vol.64, No.1, pp.55-61.

[5] KICKO-WALCZAK,E.: Thermal Stability and Fire Performance of Unsaturated Polyester Resins, Chapter 8 in Polyester: Properties, 
Preparation and Applications, edited by Hina Yamashita and Yui nakano, Nova Science Publishers, Inc. New York, 2008.

[6] CAROSIO,F., DI BLASIO,A., CUTTICA,F., ALONGI,J., MALUCELLI,G.: Flame Retardancy of Polyester and Polyester-Cotton Blends Treated with Caseins, Industrial Engeneering Chemical Research, 2014, Vol.53, pp.3917-3923.

[7] RUSMIROVIĆ,J., $\quad$ DANIČIĆ,D., $\quad$ KOVAČEVIĆ,T., BOGOSAVLJEVIĆ,M., $\quad$ BRZIĆ,S., $\quad$ MARINKOVIĆ,A., STEVANOVIĆ,T.: Phosphorylated Kraft Lignin Based Flame Retardant: Efficient Method for Improvement of Lignin Flame Retardancy and Mechanical Action in Polyester, 8th International Scientific Conference of Defensive Technologies, VTI-Belgrade, 2018, pp.538-543.

[8] SCHEIRS,J.: Additives for the Modification of Poly(ethylene Terephthalate) to Produce Engineering-grade Polymer, Chapter 14 in Modern polyester: Chemistry and Technology of Polyesters and Copolyesters, edited by John Scheirs and Timonthy E. Long. John Wiley \& Sons Ltd, 2003

[9] KOVAČEVIĆ,T., RUSMIROVIĆ,J., TOMIĆ,N., MARINOVIĆCINCOVIĆ,M., KAMBEROVIĆ,Ž., TOMIĆ,M., MARINKOVIĆ,A.: New Composites Based on Waste PET and Non-metallic Fraction from Waste Printed Circuit Boards: Mechanical and Thermal Properties, Composites Part B: Engineering, 2017, Vol.127, No.1, pp.1-14.

[10] BAUER,K., TEE,H., VELENCOSO,M., WURM,F.,: Main Chain Poly(phosphoester)s: History, Syntheses, Degradation, Bio-and Flameretardant Applications, Progress in Polymer Science, 2017, Vol.73, pp.61-122.

[11] PRIEUR,B., Modified lignin as flame retardant for polymeric materials, PhD Thesis, Universite Lille1 Sciences et Technologies France, 2018.

[12] LIU,L., QIAN,M., SONG,P., HUANG,G., YU,Y., FU,S.: Fabrication of Green Lignin-based Flame Retardants for Enhancing the Thermal and Fire Retardancy Properties of Polypropylene/wood Composites, ACS Sustainable Chemical Engineering, 2016, Vol.4, pp.2422-2431.

[13] PRIEUR,B., MEUB,M., WITTEMANN,M., KLEIN,R., BELLAYER,S., FONTAINE,G., BOURBIGOT,S.: Phosphorylation of Lignin to Flame Retard Acrylonitrile Butadiene Styrene (ABS), 2016, Polymer Degradation and Stability, Vol.127, pp.32-43.

[14] ZHANG,J., FLEURY,E., CHEN,Y., BROOK,M.A.: Flame Retardant Lignin-based Silicone Composites, RSC Advance, 2015, Vol.5, pp.103907-103914.

[15] LUO,F., NING,N.-Y., CHEN,L., SU,R., CAO,J., ZHANG,Q., FU,Q.: Effects of Compatibilizers on the Mechanical Properties of Low Density Polyethylene/lignin Blends, Chinese Journal of Polymer Science, 2009, Vol. 27, No. 6, pp. 833-842.

[16] TORIZ,G., DENES,F., YOUNG,R.A.: Lignin - polypropylene Composites. Part 1: Composites From Unmodified Lignin and Polypropylene, Polymer Composites, 2002, Vol.23, pp.816-813.

[17] THIELEMANS,W., WOOL,R.: Lignin Esters for Use in Unsaturated Thermosets: Lignin Modification and Solubility Modeling, Biomacromolecules, 2005, Vol.6, pp.1895-1905.
[18] XING,W., YUAN,H., ZHANG,P.,YANG,H., SONG,L., HU,Y.: Functionalized Lignin for Halogen-free Flame Retardant Rigid Polyurethane Foam: Preparation, Thermal Stability, Fire Performance and Mechanical Properties, Journal of Polymer Research, 2013, Vol.20, pp.1-12.

[19] COSTES,L., LAOUTID,F., AGUEDO,M., RICHEL,A., BROHEZ,S., DELVOSALLE,C., DUBOIS,P.: Phosphorus and Nitrogen Derivatization as Efficient Route for Improvement of Lignin Flame Retardant Action in PLA, European Polymer Journal, 2016, Vol.84, pp.652-667.

[20] RUSMIROVIĆ,J., TRIFKOVIĆ,K., BUGARSKI,B., PAVLOVIĆ,V., DŽUNUZOVIĆ,J., TOMIĆ,M., MARINKOVIĆ,A.: High performance Unsaturated Polyester Based Nanocomposites: Effect of Vinyl Modified Nanosilica on Mechanical Properties, eXPRESS Polymer Letters, 2016, Vol.10, No.2, pp.139-159.

[21] ASTM D882: Standard test method for tensile properties of thin plastic sheeting (2009).

[22] ISO 2555: Plastics resins in the liquid state or as emulsions or dispersions determination of apparent viscosity by the Brookfield test method.

[23] UL 94V: Standard for tests for flammability of plastic materials for parts in devices and appliances, American National Standard (2001).

[24] MANDLEKAR,N.K., CAYLA,A., RAULT,F., GIRAUD,S.S., MALUCELLI,G., GUAN,J.P.: Thermal Stability and Fire Retardant Properties of Polyamide 11 Microcomposites Containing Different Lignins, Industrial \& Engineering Chemistry Research, 2017, Vol.56, No.46, pp.13704-13714.

[25] BRZIĆ,S., RADULOVIĆ,J.: Dynamic-Mechanical Investigation of Cured Filled Polymeric System of Hydroxyl Terminated Poly(Butadiene)/Isophorone Diisocyanate, Scientific Technical Review, 2013, Vol.63, No.4, pp.32-39.

[26] YEO,J.S., LEE,J.H., HWANG,S.H.: Effects of Lignin on the Volume Shrinkage and Mechanical Properties of a Styrene/unsaturated Polyester/lignin Ternary Composite System, Composites Part B, 2017, Vol.130, pp.167-173.

[27] TASIĆ,A, RUSMIROVIĆ,J., NIKOLIĆ,J., BOŽIĆ,A., PAVLOVIĆ,V., MARINKOVIĆ,A., USKOKOVIĆ,P.: Effect of the Vinyl Modification of Multi-walled Carbon Nanotubes on the Performances of Waste Poly(ethylene terephthalate)-based Nanocomposites, Journal of Composite Materials, 2016, Vol.51, No.4, pp.491- 505 .

[28] LAYER,J., ADLER,T., AHMED,R., ALIYA,D., ANTOLOVICH,S., BAGGERLY,R.G., BAYE,R., et. al: Failure Analysis and Prevention, Vol. 11 of the ASM Handbook, edited by William T. Becker and Roch J. Shipley, 2002, ASM International, The Materials Information Company

[29] SO,P.: Fractography, Engineering Plastics, Engineered Materials Handbook, ASM International, 1988, Vol.2, pp.805.

[30] ENGEL,L., KLINGELE,H., EHRENSTEIN,G.W., SCHAPER,H.: An Atlas of Polymer Damage, Prentice-Hall, 1981.

\title{
Vatrootporni kompoziti na bazi fosfatnih estara kraft lignina i poliesterske smole: Ekološki prihvatljiv materijal za sisteme termičke zaštite raketnih goriva
}

\begin{abstract}
U radu su prikazani rezultati ispitivanja mogućnosti primene fosfatnih estara kraft lignina kao usporivača gorivosti u polimernim kompozitnim materijalima baziranim na nezasićenim poliesterskim smolama. Sinteza fosfatnih estara lignina (funkcionalizacija lignina) izvršena je direktnim graftovanjem fosforoksihlorida na slobodne polifenolne grupe iz lignina, $\mathrm{i}$ potom hidrolizom hloridnih grupa izopropil alkoholom. Maseni sadržaj čistog i funkcionalizovanog lignina u poliesterskim smolama variran je od 0,5 mas. \% do 5,0 mas. \%. Strukturna karakterizacija funkcionalizovanog kraft lignina i kompozita izvršena je primenom FT-IR spektroskopije. Proučavan je uticaj funkcionalizacije i masenog udela kraft lignina na tvrdoću, zatezna i termička svojstva nezasićenih poliesterskih smola. Rezultati ispitivanja jednoosnog istezanja pokazali su da je povećanje zatezne čvrstoće od $31 \%$ postignuto ugradnjom 1,0\% nefunkcionalizovanih čestica kraft lignina. Mehanizam nastajanja loma prilikom jednoosnog istezanja analiziran je primeneom stereomikroskopije. Termička svojstva kompozita analizirana su prema standardnoj metodi UL-94 na osnovu koje je kompozit sa 5,0 mas. \% funkcionalizovanog lignina svrstan u najvišu kategoriju termootpornih materijala, V-1, a da su zatezna svojstva i tvrdoća po Šoru (eng. Shore A) ostala zadovoljavajuća.
\end{abstract}

